\title{
Financial Distress of Registered Banking in Indonesia STOCK Exchange: Review of the Good Corporate Governance Aspect and Banking Performance
}

\author{
Wiwip Wilevy dan Augustina Kurniasih
}

\section{ABSTRACT}

\begin{abstract}
This study aims to analyse the effect of good corporate governance (GCG) mechanisms and financial performance on the Financial Distress of banks listed on the Indonesia Stock Exchange. What utilized a quantitative approach to collect the data. And the causal research design is used to examine the influences. The research population was 45 banks which are listed on the Indonesia Stock Exchange in 2019. The sample of this research was 15 banks that met the sampling criteria by purposive sampling. The results showed that Institutional, Managerial, Independent Commissioner Board Composition, Audit Committee, CAR, and LDR significantly affected financial distress. The Non-Performing Loan (NPL) has a positive and significant impact on economic desperation.
\end{abstract}

Keywords: Capital Adequacy Ratio, Non-Performing Loans, Loan to Deposit Ratio, GCG, Financial Distress.

\author{
Submitted : March 26, 2021 \\ Published : April 19, 2021 \\ ISSN: $2507-1076$ \\ DOI: $10.24018 / \mathrm{ejbmr} .2021 .6 .2 .832$ \\ Wiwip Wilevy dan Augustina \\ Kurniasih* \\ Master of Management, Mercu Buana \\ University, Jakarta, Indonesia. \\ (e-mail: wiwip.wilevy@gmail.com)
}

*Corresponding Author

\section{INTRODUCTION}

Banks have a strategic role as intermediary institutions and producers of financial services. Therefore, the prediction of financial distress in the banking sector is excellent for management in taking the right policy to prevent the bank from the risk of bankruptcy.

The measurement of financial distress in a company can do the company in various ways, including the Z-Score method. This formula uses Multiple Discriminant Analysis by combining different selected financial ratios to predict financial distress in a company [1]. A decrease in the Z-Score value in the banking sector indicates a distress condition in Indonesia's banking sector. Even since 2017, the z-score has shown that banks are experiencing financial distress.

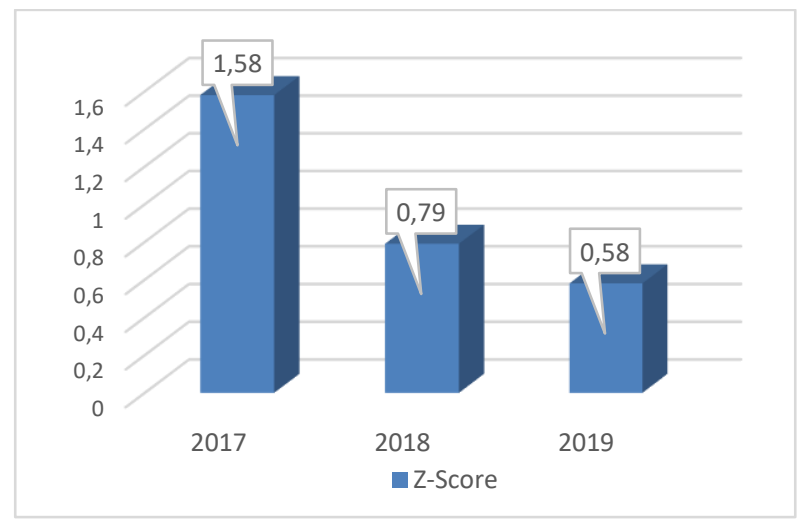

Fig.1. Z Score development Banking Sector in Indonesia.

According to [2], the company's failure in corporate governance will reduce financial performance and its longterm sustainability. Based on LPPI data [3], we know that
Good Corporate Governance (GCG) does not distribute across all Indonesian banks. Banks in the BUKU 1 and BUKU 2 categories still have performance below the national banking industry's average GCG value.

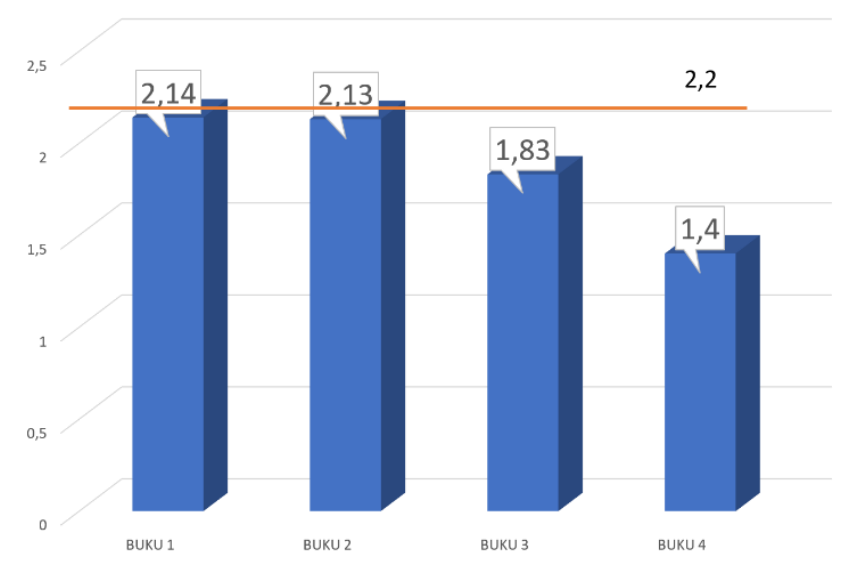

Fig. 2. Banking Industry GCG Performance.

Who found institutional dreaming to have a significant adverse effect on financial distress [4], [5]. In contrast with Pramudena's [6] research, Institutional Ownership has no significant effect on Financial Distress.

Hanafi \& Breliastiti [7] concluded that Managerial Ownership has a significant negative effect on Financial Distress. In contrasts with the research findings of [8] and [9], which show that Managerial Ownership has no significant effect on Financial Distress.

There are several banking performance variables, namely CAR, LDR, and NPL [10]. Research by [11] and [12] found that the Capital Adequacy Ratio has a significant negative effect on Financial Distress. In contrast with [13] research, 
the Capital Adequacy Ratio does not significantly affect Financial Distress.

Afiqoh \& Laila [14] and Africa [15] found that the Loan to Deposit Ratio (LDR) has a significant negative effect on Financial Distress. In contrast with [12] and [16], LDR has no significant impact on financial distress.

Research by [17] and [18] found that NPL has a significant positive effect on financial distress. That is different from Theodorus \& Artini's [19] research results, which concluded that NPL has no considerable impact on Financial Distress.

This study finds empirical evidence of the effect of good corporate governance (GCG) mechanisms and banking performance on the financial distress of banks listed on the Indonesia Stock Exchange.

\section{LITERATURE REVIEW}

The originator of this signal theory was Spence, who conducted research entitled Job Market Signaling in 1973. Spence [20] stated that asymmetric information occurs in the labor market. Therefore, Spence created a signal that adds strength to decision-making. Communication is essential for investors and businesspeople because it provides information, notes, a good description of the past, present, and future conditions regarding its business prospects and how the securities market is. Investors in the capital market need complete, relevant, accurate, and timely information as an analytical tool for making investment decisions [21].

According to [22], signal theory can also use by companies (agents), principals (company owners), and other parties to reduce information asymmetry by producing quality financial reports. Financial reports are significant for every company because they can use them to determine the company's financial performance and condition to predict the potential for bankruptcy (financial distress) in the future [23].

If the financial statements' information can be a good signal (Good News), investors will be interested in taking further steps [21]. Likewise, if the lousy sign is more reflective of financial statements, investors will switch and look for other companies with better information.

An agency relationship is a contract in which one or more people (principal) order another person to perform a service on behalf of the principal and give the agent authority to make the principal's best decisions [24]. The existence of an agency relationship between the company owner and management requires monitoring the company's financial difficulties as the primary consideration for government to take the proper steps to prevent the company from the risk of bankruptcy.

Financial distress (financial distress) is a signal or an early symptom of bankruptcy against a decline in its economic conditions. According to [25], financial distress is when a company has difficulty fulfilling its obligations, a situation in which company revenues cannot cover total costs and suffer losses. For creditors, this situation is an early symptom of debtor failure.

Altman was the first to apply multiple discriminant analyses [26]. The first Z-Score formula proposes by Altman in 1968. Multivariate discriminant analysis effectively predicts its financial difficulties because it uses several selected financial ratios [26]. The Z-score formula used is.

$$
Z=6,56 \times 1+3,26 \times 2+6,72 \times 3+1,05 \times 4
$$

Jogiyanto [21] argues that supervision and good corporate governance (GCG) can prevent its risk of loss. GCG is a method to convince investors that the company is running the company well not to hesitate to invest their funds in the company. With conducive conditions, the company will avoid the possibility of financial distress [1].

One of the links between GCG and agency theory is the finance model, which states that the separation between ownership and management can cause agency problems. The company owner will give authority to the manager (manager) to take care of the company's running of the company, such as managing funds and making other company decisions for and on behalf of the company owner.

The ability did not act in the owner's interests because of the difference in interest (conflict interest). In agency theory, share ownership is wholly own by shareholders, and the manager (agent) asks to maximize the return on the holder. With GCG, of course, it can be a tool to motivate management to maximize shareholder value.

The capital adequacy of a bank has an impact on financial condition stability [10]. CAR is a ratio that ensures a bank has sufficient funds for business development and accommodates possible losses due to bank operations [12].

The high level of bad credit at a bank indicates poor credit quality, impacting higher credit risk [27]. The higher the NPL in a bank, the higher the probability of a bank experiencing financial distress.

Liquidity is an essential factor for the health of a bank [28]. The higher the LDR ratio, the lower the liquidity capacity of the bank, and the lower the soundness of the bank, the higher the probability of a bank experiencing bankruptcy [29].

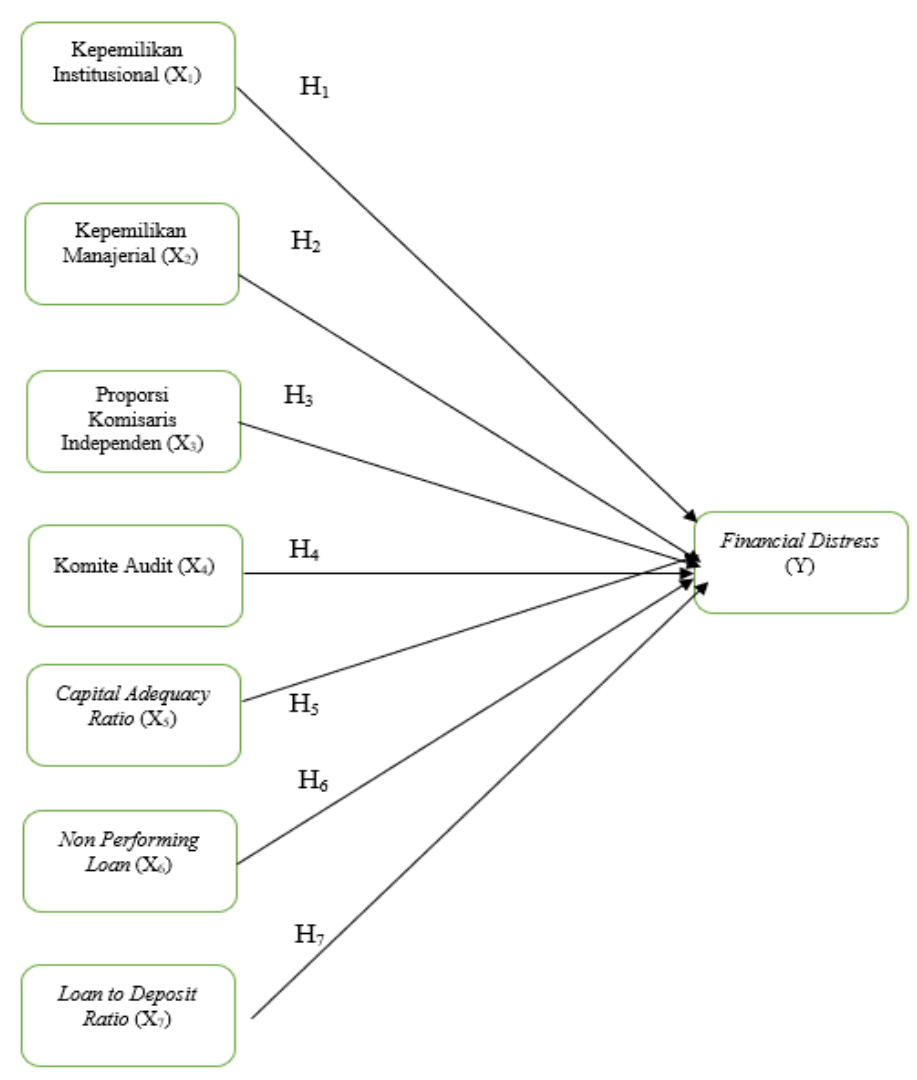

Fig. 3. Framework. 


\section{METHODS}

The causal study design use because the study examines the effects between variables.

Table I describes the operational definitions used to measure each variable.

The research population was banks listed on the Indonesia Stock Exchange (BEI) in 2019. The number is 44 banks. The sample criteria 1) Banks listed on the IDX in the 2017-2019 period, 2) Financial reports for the research period (20172019) are available. The number of companies that meet the sample criteria is 15 banks.

The effect of good corporate governance (GCG) mechanisms and financial performance on banking financial distress was analyzed using panel data regression. Panel data consists of cross-section and time-series. The regression equation proposed is:

$$
\begin{gathered}
\mathrm{Zit}=\alpha+\beta 1 \mathrm{INS}+\beta 2 \mathrm{MAN}+\beta 3 \mathrm{IND}+\beta 4 \mathrm{AUD}+\beta 5 \mathrm{CAR} \\
+\beta 6 \mathrm{NPL}+\beta 7 \mathrm{LDR}+\mathrm{e}
\end{gathered}
$$

where

$\mathrm{Z}=$ Financial Distres $(\mathrm{Z}-\mathrm{Score})$;

$\alpha=$ Constant;

$\beta 1 \mathrm{INS}=$ Institutional Ownership regression coefficient;

$\beta 2 \mathrm{MAN}=$ Managerial Ownership regression coefficient;

$\beta 3$ IND $=$ Regression coefficient of the proportion of Independent Commissioners;

$\beta 4 \mathrm{AUD}=$ Audit Committee regression coefficient;

$\beta 5 \mathrm{CAR}=$ Capital Adequacy Ratio regression coefficient;

$\beta 6 \mathrm{NPL}=$ Non Performing Loan regression coefficient;

$\beta 7 \mathrm{LDR}=$ Loan to Deposit Ratio regression coefficient;

\begin{tabular}{|c|c|c|c|}
\hline No & Variable & Measurement & Scale \\
\hline 1. & $\begin{array}{l}\text { Financial Distress } \\
\text { (Altman Z-Score) }(\mathrm{Y})\end{array}$ & $\begin{array}{l}\mathrm{Z}=6,56 \mathrm{X} 1+3,26 \mathrm{X} 2+6,72 \mathrm{X} 3+1,05 \mathrm{X} 4 \\
\mathrm{X} 1=\text { Working Capital } / \text { Total Assets } \\
\mathrm{X} 2=\text { Retained Earnings } / \text { Total Assets } \\
\mathrm{X} 3=\text { Profit before Interest and Tax / Total Assets } \\
\mathrm{X} 4=\text { Book Value of Equity/Book Value of Total Debt }\end{array}$ & \\
\hline 2 & $\begin{array}{l}\text { Institutional Ownership } \\
\left(\mathrm{X}_{1}\right)\end{array}$ & $I N S=\frac{\text { Number of Institutional Shares }}{\text { Total Number of Shares }} \times 100 \%$ & \\
\hline 3 & $\begin{array}{l}\text { Managerial ownership } \\
\left(\mathrm{X}_{2}\right)\end{array}$ & MAN $=\frac{\text { Total Management Shares }}{\text { Total Number of Shares }} \times 100 \%$ & \\
\hline 4 & $\begin{array}{l}\text { Proportion of } \\
\text { Independent } \\
\text { Commissioners }\left(\mathrm{X}_{3}\right)\end{array}$ & $I N D=\frac{\text { Number of Independent Commissioners }}{\text { Total Commissioners }} \times 100 \%$ & Ratio \\
\hline 5 & Audit Committee $\left(\mathrm{X}_{4}\right)$ & AUD $=\frac{\text { Total Audit Committee }}{\text { Total Commissioners }} \times 100 \%$ & \\
\hline 6 & $\begin{array}{l}\text { Capital Adequacy Ratio } \\
\left(\mathrm{X}_{5}\right)\end{array}$ & $C A R=\frac{\text { Owner's equity }(\text { Core }+ \text { Complement })}{A T M R} \times 100 \%$ & \\
\hline 7 & $\begin{array}{l}\text { Non Performing Loan } \\
\left(\mathrm{X}_{6}\right)\end{array}$ & $N P L=\frac{\text { Total Non }- \text { Performing Loans }}{\text { Total Credits Granted }} \times 100 \%$ & \\
\hline 8 & $\begin{array}{l}\text { Loan to Deposit Ratio } \\
\left(\mathrm{X}_{7}\right)\end{array}$ & LDR $=\frac{\text { Total Third Party Credit }}{\text { Total Third Party Funds }} \times 100 \%$ & \\
\hline
\end{tabular}
$\mathrm{e}=$ Error (annoying error).

TABLE II: DESCRIPTIVE STATISTICS OF RESEARCH VARIABLES

\begin{tabular}{ccccccccc}
\hline & Z-score & $\begin{array}{c}\text { Kepemilikan_ } \\
\text { institusional }\end{array}$ & $\begin{array}{c}\text { Kepemilikan } \\
\text { manajerial }\end{array}$ & $\begin{array}{c}\text { Komisaris_ } \\
\text { independen }\end{array}$ & Komite_audit & CAR & NPL & LDR \\
\hline Mean & 1.748 & 62.926 & 7.047 & 56.323 & 60.281 & 24.120 & 1.656 \\
Median & 1.680 & 61.000 & 0.190 & 55.550 & 50.000 & 21.380 & 1.550 & 90.100 \\
Maximum & 17.930 & 97.280 & 42.170 & 80.000 & 175.000 & 148.280 & 4.860 & 163.100 \\
Minimum & -4.250 & 4.1800 & 0.010 & 40.000 & 25.000 & 16.200 & 0.210 & 47.540 \\
\hline
\end{tabular}

\section{RESULT}

\section{A. Descriptive Statistics}

Descriptive statistics on the research variables are presented in Table II.

Financial distress, as measured by the Z-Score, has an average value of 1.74. This value shows that banks listed on the IDX are in a gray area. This is because the Z-Score value is in the range of values $1.1<\mathrm{Z}<2.6$ [30]. The lowest $\mathrm{Z}$-score of -4.25 occurred at PT.

Bank Woori Saudara 1906 Tbk (SDRA) in 2018. The negative $\mathrm{Z}$-score occurs because the company has negative working capital, or its current debt is more significant than the existing asset.

At the same time, PT received the highest $17.93 \mathrm{Z}$ score. The Indonesian National Bank Agroniaga Tbk (AGRO) will happen in 2019. Due to many undistributed profits, the bank can provide funds for the bank's operations to achieve maximum operating profit and avoid financial difficulties.

The average institutional ownership is $62.92 \%$. It shows that most companies in the banking sector are owned by institutions (institutions). PT pointed out that the lowest institutional ownership is $4.18 \%$. Indonesia Artos Indonesia Tbk Bank (ARTO) in 2018. At the same time, PT achieved the highest value of $97.28 \%$. Indonesian Malayan Bank Tbk (BNII) in 2017.

The average value of Managerial Ownership is $7.04 \%$. It shows that banking sector companies provide a small portion of company management to own the company. The lowest value of $0.01 \%$ is shown by several banks such as PT. Bank Mandiri (Persero) Tbk (BMRI) In 2017, PT. Bank Rakyat Indonesia Agroniaga Tbk (AGRO) in 2018, and PT. Bank Rakyat Indonesia (Persero) Tbk (BBRI) 2018. The highest 
value of managerial ownership is $42.17 \%$, indicated by PT. Bank Mega Tbk (MEGA) in 2017.

The average value of the proportion of independent commissioners is $56.32 \%$. It shows that, on average, companies in the banking sector have quite a lot of independent commissioners, more than half of the total company commissioners. That is expecting that many independent commissioners will encourage the use of sound governance principles and ensure that banks have information, control systems, and audit systems that can function at this properly because they place independent parties and avoid conflicts of interest. PT means the lowest 40\%. Bank BTPN Tbk (BTPN) year 2017 and PT. Bank Mega Tbk (MEGA) 2017. PT said that the proportion of independent commissioners is the highest, at $80 \%$. The National Bank of Indonesia (Persero) Tbk (BBNI) in 2019.

The average score of the Audit Committee was $60.28 \%$. Its shows that the number of audit committees to total company commissioners in companies in the banking sector is quite large. With many Audit Committees, the board of commissioners' duty to protect outsiders from corporate management fraud has helped. The audit committee is independent in carrying out its supervisory role. PT shows the lowest score of the audit committee (25\%). Indonesia's Danamon Bank Tbk (BDMN) in 2018. PT (highest score) (175\%). Woori Saudara Bank 1906 Tbk (SDRA) in 2019.

The average CAR value is $24.12 \%$. It indicates that the banking sector companies are in the "very healthy" category because the CAR value is $\geq 12 \%$ (Codification of the Institutional PBI for Bank Health Assessment, 2012). PT means the lowest CAR value is $16.20 \%$. 2019 Hatta International Bank (BBHI). The minimum value is still higher than the minimum capital adequacy ratio set by the government. At the same time, PT reached the highest value of $148.28 \%$. Indonesia Artos Indonesia Tbk Bank (ARTO) in 2019. The average non-performing loan ratio was $1.65 \%$. This value indicates that the banking sector company is in the "Excellence" category because the value of non-performing loans is $\leq 10 \%$. PT means that the lowest NPL value is $0.21 \%$. Indonesian bank Artos Indonesia Tbk (ARTO) in 2019. At the same time, PT achieved the highest score of $4.86 \%$. Who will launch the national Bank Indonesia Agricultural Bank (AGRO) in 2019? The maximum non-performing loan value is still lower than the maximum non-performing loan limit set by the government.

The average LDR value is $92.50 \%$. This value indicates that the banking sector companies are in the "fair" category because they are in the range of $85 \%<\mathrm{LDR} \leq 100 \%$, the lowest value of $47.54 \%$ achieved by PT. Bank Artos Indonesia Tbk (ARTO) in 2019. The lowest LDR value <85\% indicates that the bank is in a liquid condition. The bank has sufficient deposits to pay back withdrawals made by depositors by relying on credit provided as a liquidity source. The highest LDR value of $163.10 \%$ was achieved by PT. Bank BTPN Tbk (BTPN) 2019. The highest LDR value shows that the amount of loans to customers exceeds the number of deposits received.

\section{B. Panel Data Regression}

The selection of the best panel model shows that the Fixed Effect Model is the best. Table III shows the results of testing the regression model.

TABLE III: PANEL DATA REGRESSION ANALYSIS

\begin{tabular}{cccc}
\multicolumn{4}{c}{ TABLE III: PANEL DATA REGRESSION ANALYSIS } \\
\hline Variablee & Reg.Coef. & $\mathrm{t}_{\text {statistic }}$ & Prob \\
\hline Constanta & 15.127028 & 8.418486 & 0.0000 \\
INS & 0.567895 & 3.258804 & 0.0007 \\
MAN & 0.368839 & 2.934128 & 0.0099 \\
IND & 0.116629 & 2.261958 & 0.0335 \\
AUD & 0.200393 & 2.019127 & 0.0349 \\
CAR & 0.443693 & 3.672141 & 0.0013 \\
NPL & -3.184985 & -5.217625 & 0.0000 \\
LDR & 0.369563 & 2.572484 & 0.0295 \\
R $^{2}$ & 0.744847 & & \\
Adj-R & 0.511880 & & \\
F-statistic & & 8.197230 & 0.000000 \\
\hline
\end{tabular}

Based on Table III the resulting regression equation is:

$$
\begin{aligned}
& \mathrm{Y}=15.127+0.567 \mathrm{INS}+0.368 \mathrm{MAN}+0.116 \mathrm{IND}+ \\
& 0.200 \mathrm{AUD}+0.443 \mathrm{CAR}-3.184 \mathrm{NPL}+0.369 \mathrm{LDR}
\end{aligned}
$$

The constant is 15,127 with a significance value of 0,000 . Its means that if all the independent variables have a value of 0 (no effect), then the amount of Financial Distress (Z-Score) is 15,127 . Its means that banks are not in financial distress.

The regression coefficient value for Institutional Ownership is 0.567 with a significance value of 0.000 . It means that Institutional Ownership has a positive and significant effect. The regression coefficient indicates that if Institutional Ownership increases by one unit, the Financial Distress (Z-Score) will increase by 0.567 . Its means that the higher Its institutional ownership, the farther away it is from financial distress.

The regression coefficient value for Managerial Ownership is 0.368 with a significance value of 0.009 . It means that Managerial Ownership has a positive and significant effect. The regression coefficient number shows that if Managerial Ownership increases by one unit, the Financial Distress (ZScore) will increase by 0.368 . Its means that the higher the company's managerial ownership, the farther it is from financial distress.

The regression coefficient value for the Independent Commissioners' proportion is 0.116 with a significance value of 0.033. Its means that the balance of the Independent Commissioners has a positive and significant effect. The regression coefficient number shows that if the Independent Commissioner increases by one unit, the Financial Distress (Z-Score) will increase by 0.116 . Its means that the higher the proportion of the company's independent commissioners, the farther it is from financial distress.

The Audit Committee regression coefficient value is 0.200 with a significance value of 0.034 . It means that the Audit Committee has a positive and significant effect. The regression coefficient shows that if the Audit Committee increases by one unit, the Financial Distress (Z-Score) will increase by 0.200 . Its means that the higher the percentage of the company's audit committee, the farther it is from financial distress.

The capital adequacy ratio (CAR) is 0.443 , and the significant value is 0.001 . Its means that CAR has a positive and significant effect. The regression coefficient figures show that if CAR increases by 1 unit, the financial distress ( $\mathrm{Z}$ Score) will increase by 0.443 . Its means that the higher the company's capital adequacy ratio, the further away from 
financial distress.

The non-performing loan (NPL) regression coefficient value is $-3,184$ with a significance value of 0.000 . Its means that NPL has a negative and significant effect. The regression coefficient number shows that if the NPL increases by one unit, the Financial Distress (Z-Score) will decrease by 3,184. Its means that the higher the company's NPL, the closer to financial distress.

The regression coefficient value of the Loan to Deposit Ratio (LDR) is 0.369 with a significance value of 0.029 . Its means that LDR has a positive and significant effect. The regression coefficient number shows that if the LDR increases by one unit, the Financial Distress (Z-Score) will increase by 0.369 . Its means that the higher the LDR the company is, the farther it is from financial distress.

\section{DISCUSSION}

The results showed that Institutional Ownership has a negative and significant effect on Financial Distress. Therefore, who can conclude that the better the Institutional Ownership portion will increase the Z-Score value, which indicates the lower company's financial distress? The greater the institutional ownership, the more efficient the utilization of company assets. Thus, the proportion of institutional ownership acts as a deterrent against waste by management [31]. This study's results are in line with previous research conducted by [18] and [4] that institutional ownership has a negative and significant effect on financial distress.

The results showed that Managerial Ownership has a negative and significant effect on Financial Distress. Therefore, who can conclude that the better the Managerial Ownership portion will increase the Z-Score value, which indicates the lower company's financial distress? According to [32], the greater the managerial ownership will be to unite shareholder's and manager's interests to reduce economic pain. This study's results are in line with previous research conducted by [33], which states that Managerial has a negative and significant effect on Financial Distress.

The results show that the Independent Commissioners' composition has a negative and significant effect on financial distress. It can conclude that the higher the composition of the board of commissioners, the better its management so that it is far from the occurrence of financial distress. An independent commissioner is a corporate governance mechanism that can reduce agency problems [34]. Independent commissioners can act as intermediaries, thereby reducing asymmetric information between company management and shareholders. If both parties have the same story, what can minimize financial distress. This study's results align with Jamal \& Shah's [35] research, which shows that the Independent Commissioner's compositions have a negative and significant effect on financial distress.

The results showed that the Audit Committee had a negative and significant effect on Financial Distress. Therefore, it can conclude that the higher the composition of the audit committee, the higher the independent supervision can be carried out. The higher the management level, the better Its operation level will ultimately lead to better company performance. In other words, the tighter the management, the higher the Z-Score value, which indicates the company's financial distress is getting lower. As Hamdani [34] summarized, an influential audit committee expects to change different policies in the next few years to achieve accounting profits, thereby avoiding financial problems. This study's results are consistent with previous research conducted by [36], which showed that audit committees have a negative and significant impact on financial distress. As we all know, the audit committee usually has direct access to every company's control element. The stronger the audit committee's control, the better its management level, which can avoid financial difficulties.

The results showed that the Capital Adequacy Ratio (CAR) had a negative and significant effect on financial distress. Capital Adequacy Ratio (CAR) provides information on a bank's ability to bear risk-weighted assets with the bank's capital. The higher the CAR ratio, the higher the bank's strength in taking risky productive investment or credit, and vice versa. This study result is in line with [12], which shows that the Capital Adequacy Ratio (CAR) has a negative and significant effect on Financial Distress.

NPL founder to have a positive and significant effect on financial distress. The lower the NPL will increase the ZScore value, which indicates the company's financial distress is getting lower. As is well known, NPL shows a high number of bad credit or non-performing loans at banks. The higher the NPL, the worse the quality of bank credit, so that it will increase the cost of provision, which can result in lowering the profit received by the bank. The lower the company's profit, the more likely a bank will experience financial distress [18]. This study's results align with [17] that (NPL) positively and significantly affects financial distress.

The results showed that (LDR) had a negative and significant effect on financial distress. LDR shows the level of the bank's ability to channel collected long-term funds [27]. The higher the LDR ratio, the greater the credit extended. The greater the credit funneled, the greater the bank's chance to get interested in the loan to increase bank income. The higher the bank's income, the less likely it will be financial difficulties. This study's results are in line with the research of Ong'era et al. [29], who found (LDR) had a significant effect on financial distress.

\section{CONCLUSION}

The results showed that Institutional, Managerial, Independent Commissioner Board Composition, Audit Committee, Capital Adequacy Ratio (CAR), and LDR had a negative and significant effect on financial distress. What found Non-Performing Loans (NPL) to positively and significantly affect financial distress. The NPL shows the most important influence on economic despe It recommends that banking companies be able to keep their NPLs low. Management should focus on the collection aspect by regularly monitoring each debtor's savings account. The government also needs to observe the debtor's sales volume. A decrease in debtor sales can affect the ability to pay off debtors' obligations to banks. Management needs to take advisory actions, namely bank officers visiting customers who have indicated that they are not on time to pay credit installments. 
The next factor that has a significant influence on financial distress is institutional ownership. Management should manage the company well so that its performance increases and encourages institutional investors to want to own the company's shares. The more institutional investors are own company shares, the lower the possibility of financial distress.

The third factor that has a significant influence on banking financial distress is CAR. Management needs to manage the company's CAR to be at the level required by the regulator. The higher the CAR, the less likely financial distress will occur.

Investors planning to invest in banking stocks advise paying attention to banking performance in terms of NPL and CAR. Also Beside, if many institutional investors own bank shares, this indicates that the company is further away from the possibility of financial distress.

Researchers can then apply this research model to certain banking types, such as Islamic banks or commercial banks based on specific business categories (BUKU) (BUKU I, BUKU II, BUKU III, or BUKU IV). Future research can add other independent variables to increase the model's ability to explain problem phenomena, such as adding macroeconomic variables.

\section{LIMITATION}

This study's limitation is that it uses research objects in the banking industry to describe financial distress measurement in all sectors of companies listed on the IDX, what analyzed the research during 2017-2019. The height of financial distress is limited to the Altman z-score method so that no other way is applied to measure financial distress.

\section{REFERENCES}

[1] Jogiyanto, H. (2013). Teori Portofolio dan Analisis Investasi. BPFE.

[2] Ellen, \& Juniarti. (2013). Penerapan Good Corporate Governance, Dampaknya Terhadap Prediksi Financial Distress Pada Sektor Aneka Industri Dan Barang Konsumsi. Business Accounting Review, 1(2), 113.

[3] Lembaga Pengembangan Perbankan Indonesia. (2020). Riset-Pratik GCG: Masih dalam Tren Pemburukan. Tim Riset Majalah Stabilitas LPPI.

[4] Anggraini, D. (2014). Financial Distress Model Prediction for Indonesian Companies. International Journal of Management and Administrative Sciences (IJMAS), 3(04), 74-84.

[5] Manzaneque, M., Priego, A. M., \& Merino, E. (2016). Corporate governance effect on financial distress likelihood: Evidence from Spain. Revista de Contabilidad-Spanish Accounting Review, 19(1), 111-121. https://doi.org/10.1016/j.rcsar.2015.04.001.

[6] Pramudena, S. M. (2017). The Impact of Good Corporate Governance on Financial Distress in the Consumer Good Sector. Journal of Finance and Banking Review, 10(1), 46-55. http://journal.perbanas.id/index.php/jkp/article/view/192.

[7] Hanafi, J., \& Breliastiti, R. (2016). Peran Mekanisme Good Corporate Governance dalam Mencegah Perusahaan Mengalami Financial Distress. Jurnal Online Insan Akuntan, 1(1), 195-220.

[8] Syofyan, A., \& Herawaty, V. (2019). Pengaruh Good Corporate Governance Terhadap Financial Distress Dengan Kualitas Audit Sebagai Pemoderasinya. Prosiding Seminar Nasional Cendekiawan, 2015, 2. https://doi.org/10.25105/semnas.v0i0.5827.

[9] Harahap, L. W. (2017). Pengaruh Mekanisme CG dan UP Terhadap Kondisi FD Pada Perusahaan Property and Real Estate yang Terdaftar di BEI Tahun 2010 - 2014. Jurnal Riset Akuntansi \& Bisnis, 17(2).

[10] Darmawi, H. (2011). Manajemen Perbankan. Bumi Aksara.

[11] Karugu, C., Achoki, G., \& Kiriri, P. (2018). Capital Adequacy Ratios as Predictors of Financial Distress in Kenyan Commercial Banks.
Journal of Financial Risk Management, 07(03), 278-289. https://doi.org/10.4236/jfrm.2018.73018.

[12] Zahronyana, B. D., \& Mahardika, D. P. (2018). Capital Adequacy Ratio, Non Performing Loan, Net Interest Margin, Biaya Operasional Pendapatan Operasional Dan Loan To Deposit Ratio Terhadap Financial Distress. Jurnal Riset Akuntansi Kontemporer, 10(2), 90-98.

[13] Nuranto, A. A., \& Ardiansari, A. (2017). Pengaruh Rasio Keuangan, Firm Size, dan Market Effect Terhadap Tingkat Kebangkrutan. Management Analysis Journal, 6(2), 185-194. http://maj.unnes.ac.id.

[14] Afiqoh, L., \& Laila, N. (2018). Pengaruh Kinerja Keuangan Terhadap Risiko Kebangkrutan Bank Umum Syariah Di Indonesia (Metode Altman Z-Score Modifikasi Periode 2011-2017). Jurnal Ekonomi Dan Bisnis Islam (Journal of Islamic Economics and Business), 4(2), 166 https://doi.org/10.20473/jebis.v4i2.10757.

[15] Africa, L. A. (2018). Bankometer Models for Predicting Financial Distress in Banking Industry. Jurnal Keuangan Dan Perbankan, 22(2), 373-379. https://doi.org/10.26905/jkdp.v22i2.2050.

[16] Sihombing, P., \& Sundoro, H. S. (2019). Pengaruh Faktor Makroekonomi Dan Likuiditas Terhadap Yield Curve Obligasi Pemerintah Indonesia. Media Ekonomi, 25(2), 117. https://doi.org/10.25105/me.v25i2.4894.

[17] Budiman, T., Herwany, A., \& Kristanti, F. T. (2017). An Evaluation of Financial Stress for Islamic Banks in Indonesia Using a Bankometer Model. Journal of Finance and Banking Review, 2(3), 14-20.

[18] Mazzù, S., \& Muriana, F. (2018). A Strategic Approach to NonPerforming Loans Treatment in Banking: Options and Rules for Decision-Making. International Research Journal of Finance and Economics, 166, 34-53.

[19] Theodorus, S., \& Artini, L. G. S. (2018). Studi Financial Distress Pada Perusahaan Perbankan Di Bei. E-Jurnal Manajemen Universitas Udayana, $\quad 7(5)$, https://doi.org/10.24843/ejmunud.2018.v07.i05.p16.

[20] Spence, M. 1973. Job Market Signaling. The Quarterly Journal of Economics, 87(3). (Aug, 1973), 355-374.

[21] Jogiyanto, H. (2015). Teori Portofolio dan Analisis Investasi. BPFE

[22] Husnan, S. (2015). Dasar-Dasar Teori Portofolio dan Analisis Sekuritas. BPFE.

[23] Husnan, S., \& Enny, P. (2016). Dasar-Dasar Manajemen Keuangan. UPP STIM YKPN.

[24] Scott, W. (2012). Financial Accounting Theory International (fifth edit). Prentice Hall Inc.

[25] Hery. (2016). Analisis Laporan Keuangan Integrated and Comprehensive Edition. PT. Gramedia Pustaka Utama.

[26] Rudianto. (2013). Akuntansi Manajemen Informasi Untuk Pengambilan Keputusan Strategis. erlangga.

[27] Taswan. (2015). Akuntansi Perbankan. UPP STIM YKPN.

[28] Kasmir. (2016). Analisis Laporan Keuangan. Raja Grafindo Persada.

[29] Ong'era, J. B., Muturi, W., Oluoch, O., \& Karanja, J. N. (2017). Leverage as Financial Antecedent to Financial Distress among Listed Companies at Nairobi Securities Exchange. Research Journal of Finance and Accounting, 8(6), 95-104.

[30] Jan, A., \& Marimuthu, M. (2015). Al Bankruptcy Profile of Foreign versus Domestic Islamic Banks of Malaysia: A Post Crisis Period Analysis. International Journal of Economics and Financial Issues, $6(1), 332-346$.

[31] Riyanto, B. (2013). Dasar-Dasar Pembelanjaan Perusahaan. BPFE.

[32] Hastuti, I. (2014). Pengaruh Struktur Kepemilikan Terhadap Kemungkinan Kesulitan Keuangan Pada Bursa Efek Indonesia. Jurnal Ekonomi Manajemen Sumber Daya, 15(2), 13-20.

[33] John, A., \& Lawrence, O. (2018). Corporate Governance and Financial Distress in the Banking Industry: Nigerian Experience. Journal of Economics and Behavioral Studies, 10(1).

[34] Hamdani. (2016). Good Corporate Governance (Tinjauan Etika dalam Praktik Bisnis. mitra wacana media.

[35] Jamal, A. H., \& Shah, S. Z. A. (2017). The Impact of Corporate Governance on the Financial Distress: Evidence from Pakistani Listed Companies. Jinnah Business Review, 5(2), 5.

[36] Partha, I. M. B. (2019). Effect of audit committee characteristics on relationship between financial distress and income maximization actions. International Journal of Social Sciences and Humanities, 3(3), 28-35. https://doi.org/10.29332/ijssh.v3n3.343. 